\title{
Introduction: Reconnecting with Existentialism in an Age of Human Capital
}

\author{
Herner Saeverot $\cdot$ Solveig M. Reindal $\cdot$ Stein M. Wivestad
}

Published online: 6 August 2013

(C) Springer Science+Business Media Dordrecht 2013

At the end of the 1950s Otto Bollnow connected existential philosophy with education, and the expression existential education was later used by people such as Morris (1966), Segal (1998), and Maclaren (2008). Through this special issue we hope to contribute to the development of the concept of existential education and to an understanding of how existential education may be integrated into a general educational theory. Our point of departure when it comes to the definition of the concept of existential education is the article Kierkegaard, seduction, and existential education (Saeverot 2011, pp. 559-560). One of the key points that was stated there was that human beings do not possess an inner, objective truth. Thus existential education is not about obtaining objective truth, it is rather a matter of obtaining subjective truth. A premise of subjective truth is that one can never force upon another a meaning, persuasion or belief. The student must rather appropriate the existential communication from the teacher, make it into something subjective and personal, not only in order to think differently, but to start acting differently as well.

Thus the notion of existential education, and this we are about to argue in more detail, stands in sharp contrast to the human capital theory, which is spreading in the current political and educational landscape. Take, for example, the modern knowledge society-in which knowledge is understood as a commodity that shall be converted for the best of community (Barnett 1994, p. 48). Therein, the modern employer provides, among other things, courses on motivation and well-being. The goal here is not only to improve the employee's motivation and well-being, but also to reduce absenteeism, and-not the

H. Saeverot $(\square)$

Department of Education, University of Bergen, PB 7807, 5020 Bergen, Norway

e-mail: herner.saverot@psych.uib.no

S. M. Reindal

NLA University College, Sandviken, P.O. Box 74, 5812 Bergen, Norway

e-mail: SolveigM.Reindal@NLA.no

S. M. Wivestad

Department of Education, Norsk Lærerakademi University College, Sandviken,

PO Box 74, 5812 Bergen, Norway

e-mail: sw@nla.no 
least-to improve corporate profitability. Generally speaking, the purpose is to create harmony between corporate goals and visions on one side and the employees on the other. The reason is that this will provide the best opportunities for prosperity and cooperation between employer and employee, as well as increasing productivity and profits. Achieving a good working environment, which includes prosperity, collaboration, etc., suggests that the idea of human capital, which briefly can be defined as the single individual's skills, knowledge and competence, is given the best growing conditions (Robeyns 2006). Therefore it is important to ensure that there is no disharmony between employees and corporate strategies and objectives, as this will give poor growing conditions for human capital, after which the employer will benefit less from the employees.

Concepts of human capital have become more and more prominent in school policy, too. The idea is that it is important to utilize knowledge, which is equivalent to cultivating human capital, as it will be an important factor for competitiveness in a global economy. In other words, the knowledge or competence of each citizen will contribute to wealth creation and economic growth for the society. Therefore, politicians and other actors wish to create the best growing conditions for human capital in schools, as it is an important resource in terms of developing future welfare and increasing the economic profit of the society.

It can further be argued that students are seen as entrepreneurs who shall initiate and conduct the school's visions and goals because they are considered to be an investment that will provide financial profits, as this policy document clearly shows: "The challenge of Norwegian knowledge policy is this: The country is not obtaining enough competency from the talents of the population" (NOU 1988: 28, p. 7; our translation). Therefore, the good life is easily defined as developing one's abilities and talents. Without further ado, the contradictory conflict between social economic benefits on the one side and living a good life on the other side is simply revoked. The problematising around this complex relationship is entirely absent, a claim that is supported by Gilead:

Today, economic progress is one of the central aims of education. Powerful supranational organizations, such as the OECD and the World Bank, view education primarily as a tool for improving economic performance. According to the World Bank's website, education is important because it lays the foundations for sustained economic growth. In 2007 the OECD's main webpage on education plainly stated that 'both individuals and countries benefit from education. For individuals, the potential benefits lie in general quality of life and in the economic returns of sustained, satisfying employment. For countries, the potential benefits lie in economic growth and the development of shared values that underpin social cohesion.' Nothing further is added about the non-economic benefits or functions of education. (Gilead 2012, p. 113)

The politicians and others who govern the school simply take it for granted that each student can live a good life while at the same time emerge as an important resource and contributor to the national economy. ${ }^{1}$ But what's being overlooked, in our opinion, is that the students at the same time are directed into a particular way of existing. It is presupposed that the students are reduced to beings who are completely determined by their

\footnotetext{
${ }^{1}$ In fact, this has, from the very beginning, been an agenda within Marxism. For example, alienation was related to the process of production, and if one had the power over the production means, that would free the subject from alienation. Freeing the subject from alienation is a process of realising the 'good life,' hence the Marxist conception of man has been linked to the man who produces, for the best of society.
} 
abilities, their biological heritage. This form of, let's say, "biological pedagogy," which has a one-sided emphasis on the development of skills, will lead to a lonely or nonrelational form of existence. To develop one's skills is all about developing abilities that can maximise one's own interests and utilities. Thus it could lead to irresponsibility with respect to fellow human beings. In an existential perspective this is a very limited view of humanity and its role in the world, partly because the profoundness that the meeting and the relationship with other people entails, is deprived of the student.

What is thought-provoking is that we find the same types of concepts in both human capital thinking and existentialism, such as freedom, choice and responsibility; however, it is very important to note that these concepts are used in very different ways, ways that lead to entirely different concepts of man. How might that be so?

Take for example the freedom to realise ourselves as human beings. Whereas previous generations did not have as much opportunities to realise themselves, there is nowadays a strong focus on self-realisation and individualisation in schools. It is about cultivating the individuals' idiosyncrasies, because that is the usual way of defining us as human beings. At the same time the human capital idea must be cultivated, which coerces individuals into another role: namely, the role of an entrepreneur. To complement this role, the individual must make the most out of themselves, after which the process of self-realisation on the one side and the school's profitability on the other are two sides of same coin. Thus the individuals themselves have become a kind of commodity, a situation which they are not free to opt out - if, that is, they want to remain within the system. The individuals must act according to the system's indirect demand, that is, the demand to cultivate themselves in the context of what is considered to be useful and profitable. What's useful and profitable in the context of schools are skills and knowledge, particularly the kind of skills and knowledge that can be measured. However, the unfortunate consequence is thus: that which falls outside this scale is considered useless, unprofitable and worthless.

And what about responsibility? In fact, there is also much focus on responsibility in the age of human capital, where one of the educational mantras reads thus: you should be responsible for your own learning. Such a change in practice is often characterized as a shift 'from teaching to learning' - a shift which is part of a wider 'learnification' of educational discourse and practice, as pointed out in Gert Biesta's paper (this issue) Receiving the gift of teaching: From 'learning from' to 'being taught.' This is a typical example of removing responsibility from both teachers and school administrators. The responsibility for learning is transferred to the students, who have to identify themselves with the school's visions and values, after which they must assume their responsibilities as entrepreneurs. This leads to an individualised understanding of responsibility, where everyone shall cultivate themselves and also develop their skills. The consequence is that this view of responsibility, where the human capital theory is the basis, strengthens students' egocentricity and lack of responsible actions - in other words, it hides a deep moral betrayal in relation to having responsibility for the other and to the world as such.

As a consequence of the human capital mindset we have reached a mis-educative form of education, where the students are slaves of the society and its interests. This is further explained by Robeyns:

human capital theory cannot explain the behaviour of someone who wants to spend her time studying something without any prospect of economic returns from this education. In human capital theory, as in the other parts of mainstream economics, human beings act for economic reasons only. That people might act for social, religious, moral, emotional, or other non-economic reasons, cannot be accounted for 
by this theory. The second problem with human capital theory is that it is entirely instrumental: it values education, skills and knowledge only in so far as they contribute (directly or indirectly) to expected economic productivity (Robeyns 2006, pp. 72-73; emphasis in original).

Because of its very strong uniformity, economic and instrumental conditioning, which ultimately treats students as objects, the human capital mindset contradicts humane existence. Therefore it is important to reconnect with existentialism in education, important as existentialism always has represented a form of criticism of such ways of objectifying people. A special feature in existentialism is to treat people as subjects, who must be free, but not without assuming responsibility for their surroundings.

This is evident in Sartre, who most people associate with the concept of existentialism. In October 1945 he held the now famous lecture Existentialism is a humanism, where he mainly tries to defend existentialism against several reproaches that have been laid against it, including the claim that existentialists "remain in a state of quietism and despair" (Sartre 2007, p. 17). Sartre (ibid., p. 34-35) seems to accept the claim that despair is a feature in life that we must try to overcome. Therefore it is very interesting to read Peter Robert's paper in this special issue-Happiness, despair and education-which actually argues, by way of Dostoevsky et al., that despair is a defining feature of human life. Accordingly, Roberts is critical of education's seemingly obsession with 'happiness,' whereupon discomfortable dimensions of life that we all have to go through, including despair, are swept under the rug. Rather, education must be open to such dimensions, according to Roberts, but without neglecting or undermining the pain that despair may cause.

If we return to Sartre's lecture, we notice that his ambition is to address the following question: What is existentialism? The answer is simply "that existence precedes essence; or, if you prefer, that subjectivity must be our point of departure" (Sartre 2007, p. 20), a thesis that Sartre explains in more detail in the following quote:

What do we mean here by 'existence precedes essence'? We mean that man first exists: he materializes in the world, encounters himself, and only afterwards defines himself. If man as the existentialists conceive of him cannot be defined, it is because to begin with he is nothing. He will not be anything until later, and then he will be what he makes of himself. Thus, there is no human nature since there is no God to conceive of it. Man is not only that which he conceives himself to be, but that which he wills himself to be, and since he conceives of himself only after he exists, just as he wills himself to be after being thrown into existence, man is nothing other than what he makes of himself. This is the first principle of existentialism. (ibid., p. 22)

These points of view are related to the fact that Sartre was an atheist. He says that he represents an atheistic existentialism, where God does not exist, as opposed to, for example, Christian existentialism. According to Sartre all people are free to choose themselves, hence existence precedes essence.

Several of the contributors of this special issue discuss the relationship between existence and essence. For example, Nigel Tubbs, unlike Sartre, will not decide a priority, but understands the relation between essence and existence as a struggle, which follows the imperative Know Thyself. Leaning on Hegel, Tubbs argues that immediacy (intuition in what is, the essential) necessarily is combined with mediation (our concepts). Thus he repudiates the Aristotelian understanding of essence as something in-itself, which cannot be otherwise than it is. What is in-itself (essence) is dependent on subjective experience 
(existence), and is therefore always otherwise. In the existential logic of Know Thyself, the search for truth is seen as a process of education: Essence and existence has to learn from each other.

Rene Arcilla, on the other hand, reads Sartre's lecture in a different way, that is, he emphasizes that our interests must be affirmed as free responses to our thrownness into existence-rather than, as John Rawls argues in A theory of justice, being affirmed by viable principles. However, in order for these free choices to become responsible, we must commit ourselves to our communal nature, our camaraderie, and to participate unselfishly in the endless conversation of justice. While these ideas correspond with Sartre's ideas in several ways, they do not correspond with Sartre's (2007, p. 35) war rhetoric ("my comrades-in-arms in the struggle").

In Irony, deception, and subjective truth: Principles for existential teaching (this issue) Herner Saeverot challenges, indirectly, Sartre's ideas of subjectivity, as he introduces, by way of Kierkegaard, a meta-rhetorical concept of irony-which is different from, for example, simple forms of irony in which one says the opposite of what one actually means. The latter concept of irony has to do with asserting control and authority as the ironist gives a gift by way of him- or herself, meaning that the ironist is trying to escort the recipient into believing what is indirectly said. Such types of irony thus lack the kind of dimension or power that we find in meta-rhetorical irony, that is, a power that can move the recipients in relation to themselves. Where the first kind of irony relates to objective truth, the metarhetorical concept of irony relates to subjective or existential truth, that is, a kind of truth that is true for the single individual, and no one else.

This kind of existential education has to do with freedom, as it is not about subjecting oneself to a unique power that exhorts individuals to go in a certain direction. Unlike an admonition, existential education does not require anything. The recipients may as well say no, and it is this openness that makes room for freedom; freedom to choose and freedom to make what is communicated relevant to their own existence. Hence we may say that the existential education is about existing in relation to subjective truth, which goes beyond the standards and uniformities of the idea of human capital. For example, the child who "grows up" as a person emulates adult exemplars, both inside and outside school situations. Whether we intend it or not, we give the child examples of what it is to live as a human being. Following Kierkegaard's concept of upbuilding and his practice of indirect communication, Stein M. Wivestad (this issue) searches for Upbuilding examples in music, literature, pictures and films; works of art that can help informal groups of adults in their struggle with themselves as models for children. The interest of such an existential education is to become free through being an active and a responsible person.

This is not only a completely different way of thinking than the instrumentalist belief of human capital theory, but it is also completely different from progressive education. For example, the progressive educator Dewey, in who the social conception of freedom and subjectivity dominates, "does remain caught in an instrumentalistic approach, in that he sees participation in democracy as the way in which the socially intelligent person is created or produced" (Biesta 2006, p. 132). In sharp contrast to Dewey's conception of the free and democratic person as the one who uses education in order to learn and grow, Biesta (this issue) highlights a fundamental distinction between two existential possibilities within educational relationships: one where we learn from our teachers and one where we are being taught by our teachers. He thus turns education back to the question of teaching, emphasising that the experience of being taught cannot be produced by teachers-it is beyond their control-but can enter as an event or a gift. In this way Biesta highlights the existential dimensions of education; dimensions that in our times are significantly 
underestimated. Take, for example, all the crises we face today, crises within democracy, economy, environment etc. In our struggle with these crises and attempts to prevent new ones, all of us must, as we see it, retake a direct personal responsibility with regard to our fellow human beings and our surroundings. Therefore, the existential aspect must not only be represented in, but actually permeate the content of education.

Do we here stand before a paradox? For while society is increasingly exposed to terror, fanaticism and strong and uniform ideologies, education is becoming more uniform and streamlined, so that investors, mostly politicians, can be sure that they get value for their money. We argue in this special issue that an education which is one-sidedly directed towards what is useful, will lack the depth that is necessary in order to prevent possible misuse of skills, knowledge and competencies. This is also a lesson that history has taught us. Consider, for example, the second world war and the recent terror attacks. These events testify that some educated people, with the highest university learning outcomes, had no scruples when it came to killing other people. A type of education where the students learn knowledge, skills and general competencies with short-term utility in focus, does not give enough resistance to such atrocities. The educational system under the influence of human capital is more concerned with knowledge as commodity rather than the bearer of knowledge. In her paper Bildung, the Bologna process and Kierkegaard's concept of subjective thinking (this issue) Solveig M. Reindal argues that knowing something also implies an ethical demand on the bearer. She proposes that Kierkegaard's notion of subjective thinking can help to initiate a thinking that makes it possible to act responsibly in relation to the knowledge one holds. Of course there are never any guarantees in preventing that atrocities occur, but we still believe that "existential education" may have a preventive effect against various forms of cruel acts, primarily because it creates possibilities for stepping out of an existence as a functional "atom" or "brick in the wall," and into a relational form of existence.

\section{References}

Barnett, R. (1994). The limits of competence: Knowledge, higher education, and society. Buckingham: Open University Press.

Biesta, G. J. J. (2006). Beyond learning: Democratic education for a human future. Boulder, Co: Paradigm Publishers.

Gilead, T. (2012). Education and the logic of economic progress. Journal of Philosophy of Education, 46(1), $113-131$.

KUF. (1988). Med viten og vilje [Knowingly and intentionally]. Oslo: NOU.

Maclaren, K. (2008). The role of emotion in an existential education: Insights from Hegel and Plato. International Philosophical Quarterly, 48(4), 471-492.

Morris, V. C. (1966). Existentialism in education: What it means. New York: Harper \& Row.

Robeyns, I. (2006). Three models of education: Rights, capabilities and human capital. Theory and Research in Education, 4(1), 69-84.

Saeverot, H. (2011). Kierkegaard, seduction, and existential education. Studies in Philosophy and Education, 30(6), 557-572.

Sartre, J.-P. (2007). Existentialism is a humanism (C. Macomber, Trans.). New Haven \& London: Yale University Press.

Segal, S. (1998). The anxiety of strangers and the fear of enemies. Studies in Philosophy and Education, 17(4), 271-282. 